Forthcoming in Sociology of Religion

\title{
Christian America in Black and White: Racial Identity, Religious-National Group Boundaries, and Explanations for Racial Inequality
}

\author{
Samuel L. Perry \\ University of Oklahoma \\ Andrew L. Whitehead \\ Clemson University
}

\begin{abstract}
Recent research suggests that, for white Americans, conflating national and religious group identities is strongly associated with racism, xenophobia, and Islamophobia, prompting some to argue that claims about Christianity being central to American identity are essentially about reinforcing white supremacy. Prior work has not considered, however, whether such beliefs may influence the racial views of non-white Americans differently from white Americans. Drawing on a representative sample of black and white Americans from the 2014 General Social Survey, and focusing on explanations for racial inequality as the outcome, we show that, contrary to white Americans, black Americans who view being a Christian as essential to being an American are actually more likely to attribute black-white inequality to structural issues and less to blacks' individual shortcomings. Our findings suggest that, for black Americans, connecting being American to being Christian does not necessarily bolster white supremacy, but may instead evoke and sustain ideals of racial justice.
\end{abstract}

Keywords: Christian America, racism, racial inequality, black Americans, religion 
A centerpiece of Donald Trump's presidency—a presidency now famous for heightened racial strife and the emboldening of white supremacists-is a commitment to defend America's supposed "Christian heritage." Trump announced to his audience at Oral Roberts University during his campaign "There is an assault on Christianity... There is an assault on everything we stand for, and we're going to stop the assault" (Justice and Berglund 2016). Likewise, he assured a group of pastors in Florida months before the election, "You know that Christianity and everything we're talking about today has had a very, very tough time... We're going to bring [Christianity] back because it's a good thing... They treated you like it was a bad thing, but it's a great thing” (C-Span 2016a). And he rallied his listeners at Liberty University, "[Americans] have to band together... Our country has to do that around Christianity" (C-Span 2016b). Though himself a notoriously-impious man, Trump was strategically tapping into what has been described as a resurgence of primarily white Americans and politicians calling forth a trope about the historical and vital connection between American citizenship and Christianity (Braunstein 2018; Braunstein and Taylor 2017; Gorski 2017a; Jones 2016).

Consistent with what we might expect given Trump's "Christian nationalist" rhetoric, believing more firmly in this supposed connection between Christian and American identities was among the strongest predictors of voting for Trump in November 2016 (Sides 2017; Stewart 2018; Whitehead, Perry, and Baker 2018). But more than just a pining for America's fading religious heritage, scholars suggest that behind this belief that conflates Christian and American identities is ultimately a defense of white supremacy. That is to say, Americans who see their religious and national group memberships as overlapping and sacred, may in essence be drawing symbolic boundaries around and defending white racial group membership and privileges (Gorski 2017b). While there is certainly evidence to support that claim among white Americans 
(Edgell and Tranby 2010; McDaniel, Nooruddin, and Shortle 2011; Perry and Whitehead 2015a, 2015b; Shortle and Gaddie 2015), studies have yet to empirically examine how these beliefs among non-white Americans affect their racial views compared to whites. It may be that, for racial minorities who occupy a different structural location than whites, a belief in America's essentially-Christian identity reveals an underlying theology of citizenship and justice that does not bolster white supremacy, but in fact challenges it.

Using nationally representative data on black and white Americans from the 2014 General Social Survey, and focusing on explanations of black-white inequality as the outcome, we test whether racial identity moderates the potential link between conflating Christian and American identities and holding views that either support or challenge dominant white racial frames (Cobb, Perry, and Dougherty 2015; see also Bonilla-Silva 2009; Feagin 2013). We demonstrate that, in contrast to white Americans, black Americans who affirm that being a Christian is very important to being truly American are actually more likely to attribute blackwhite inequality to racial discrimination and educational opportunities, and are less likely to explain inequality in terms of blacks' own supposed lack of motivation. Our study thus advances our understanding of both the racial content of contemporary claims for America to "remember" its Christian heritage, as well as our understanding of how black Americans' theologies of national responsibility shape their interpretation of "Christian America" differently than whites.

\section{Background}

\section{Interpretations of the United States as a "Christian Nation" and Racial Attitudes}

Religious nationalism in the United States has been steeped in white supremacy from its beginnings (Gorski 2017a). Drawing on narratives of Old Testament Israelites, who were demanded to maintain blood and cultural purity through ethnic endogamy and conquest, many 
white Christian Americans historically conceived of themselves as the "new Israel" (Aho 2013; Cherry 1998; Goldberg 2006) thus implying similar standards. While some scholars thought the explicitly racialist content of this sort of "Christian nationalism" were attenuated over time, recent research suggests that white racial boundary-maintenance has remained one of the foremost hallmarks of whites who today argue that America's identity is (and should be) fundamentally Christian (Braunstein 2017, 2018; Goldberg 2006; Gorski 2017b; Straughn and Feld 2010; Williams 2013). Notably, research suggests that this sort of identity-conflation is not merely a proxy for religious parochialism or political conservatism. Rather, its robust influence on white racial attitudes reveals something unique about the racialized ideals undergirding claims about America being a "Christian nation.” McDaniel, Nooruddin, and Shortle (2011), for example, found that while white evangelicals were statistically more likely than other groups to hold anti-immigrant sentiments, this association disappeared once the authors controlled for whether respondents believed the US had a special relationship with the Christian God that should be preserved. The connection between white evangelicals and xenophobia, in other words, was less about religious conservatism per se, and more about the threat many of these Americans perceive to national identity, which they view as both Christian and white (see also Delehanty, Edgell, and Stewart 2017; Jones 2016).

Other studies have similarly found that whites who identify the United States as a "Christian nation" tend to draw more rigid boundaries around national membership (Edgell and Tranby 2010; McDaniel, Nooruddin, and Shortle 2015). These boundaries tend to exclude Muslims in particular (Merino 2010; Sherkat and Lehman 2018; Shortle and Gaddie 2015) who have in recent years come to be conceived of as a non-white racial group in the American popular consciousness. And recently, work by Davis (2018a) has shown that white Americans 
who hold firmly to America's distinctively Christian identity are more likely to favor the death penalty and the federal government "cracking down" on troublemakers, which other studies have shown is often dog-whistle language for black Americans, assumed to be criminal (see Alexander 2012:40-58).

Attempting to draw out the explicitly racial content of "Christian nationalist" claims, Perry and Whitehead (2015a, 2015b) found that white Americans who held firmly to a belief about America's Christian heritage and identity tended to be less supportive of interracial family relationships, even after controlling for a battery of religious and political characteristics and even interracial friendships. Collectively, these findings prompted Perry and Whitehead (2015b:131) to conclude that, "within the racialized social system of the United States, Christian nationalist ideology is inextricably linked with notions of [white] purity and separation." Importantly, however, studies exploring the connections between religious and national-group boundaries and racial ideologies have yet to consider whether non-white Americans who connect being Christian with being an American are also more likely to hold racial attitudes that bolster white supremacy. ${ }^{1}$ Focusing on black Americans in particular, we theorize that this is not necessarily the case.

Race, Structural Location, and Alternative Interpretations of the America's Christian Identity Collins (1986) famously observed that those who occupy historically marginalized spaces within society (within her argument, black women), maintain a unique "standpoint" that enables them to perceive cultural and social arrangements in ways that are often overlooked by those in

\footnotetext{
${ }^{1}$ While several of the studies we have cited report testing for interactions between Christian nationalist measures and race, and notably report no significant differences, these studies have either focused on the white/non-white dichotomy and/or have utilized samples with too few representatives from specific minority groups to draw meaningful conclusions (e.g., Davis 2018a; Perry and Whitehead 2015a, 2015b; Perry et al. 2018). Our study thus improves on these previous examinations empirically as well as conceptually.
} 
power. While it is a fundamental sociological observation that actors' structural location within society's stratification scheme differentially shapes their perceptions of inequality (Berger 1967; Marx [1844] 1977; Weber [1922] 1993), Collins's work points us to the ways cultural elements that inhere within our racialized society can either justify or challenge that inequality. Focusing on religion's diverse influences within America's racialized social system, scholars have long recognized the tendency of white Americans to appeal to Christianity as a means of justifying racial hierarchies and racist institutions, including slavery, segregation, and more recently, welfare retrenchment (for reviews, see Edwards, Christerson, and Emerson 2013; Emerson, Korver-Glenn, and Douds 2015). In contrast to this, scholars have argued that a "humanist tradition" (Collins 1986:521), "social justice orientation” (Brown 2009), and beliefs about black empowerment are fundamental to black community life, and can be seen in the ways black Americans have reinterpreted Christianity to fit their structural location (Barnes 2005; CahlhounBrown 1999; Cone 1997; Harris 1999; Lincoln and Mamiya 1990; Patillo-McCoy 1998; Shelton and Emerson 2012; Wilmore 1973). Consistent with this idea, recent research demonstrates that racial identity moderates the link between religious characteristics and Americans' explanations for racial inequality. Using data from the 2014 Boundaries in American Mosaic Survey, Frost and Edgell (2017) found that "religious orthodoxy" (a composite measure that includes a question affirming the link between society's laws and God's laws) reduced support for structural explanations for racial inequality among white Americans, but it actually promoted stronger support for these explanations among blacks and Hispanics.

To be sure, the experience of systemic oppression has led numerous black American authors and scholars to excoriate America's ostensibly "Christian” heritage as hypocrisy and deception, viewing America as essentially anti-Christian (e.g., Cone 1969, 1997; Douglass 
1845:101-108; Wilmore 1973). Indeed, this view influenced many black thought-leaders during the Civil Rights Movement and afterwards toward a separatist form of Christian nationalism with blacks remaining as autonomous from whites as possible (e.g., Cleage 1972; Cone 1969). But importantly, the racial justice elements shaping many black Americans' views of religion and society has also influenced some to reinterpret America's Christian heritage not in terms of what it has been, but what it should have been and could be. While some scholars (e.g., Paris 1985) argued that Christianity promoted a loyalty to America's civic order that constrained the activism of black Americans, others (e.g., Harris 1999; Morris 1984) show how Christian ideals, symbols, and structures of organization blended with ideals of citizenship and civic-mindedness to mobilize black activists during the Civil Rights Movement.

Other black Christian leaders have explicitly drawn on the rhetorical device of "Christian America" to catalyze social change. Martin Luther King Jr., for example, regularly challenged America to live up to its professed Christian identity. Using a fictional letter from the Apostle Paul to American Christians as an illustrative tool, King (1956) preached, “Oh America, how often have you taken necessities from the masses to give luxuries to the classes. If you are to be a truly Christian nation you must solve this problem." Most famously, King (1963) reminded the clergy of Birmingham that "[Black Americans] will win our freedom because the sacred heritage of our nation and the eternal will of God are embodied in our echoing demands." Later in his Letter from a Birmingham Jail, King declared that those who fight for racial justice are fighting for "what is best in the American dream and for the most sacred values in our Judeo-Christian heritage, thereby bringing our nation back to those great wells of democracy which were dug deep by the founding fathers..." In both quotes, King draws a connection between America's 
founding ideals and its Christian heritage, but his connection underscores a commitment to racial justice.

More than this, King's Letter emphasized that America's Christian ideals would only be truly realized by racial justice resulting from structural policy changes (in his case, ending segregation). Scholars have argued that this commitment to structural transformation is also fundamental to the civic and religious orientations of black Americans (e.g., Cone 1997; Paris 1985). Articulating a vision of Jesus' resurrection as a "political event," Cone (1997:115) explained that belief in the resurrection "requires that [blacks] practice political activity against the social and economic structure that makes them poor. Not to fight is to deny the freedom of the resurrection. It is to deny the reality of Christ's presence with us in the struggle to liberate slaves from bondage." Describing how the experience of discrimination has shaped the black American "sacred cosmos" (the term taken from Lincoln and Mamiya 1990), Shelton and Emerson (2012:169) argue that "the black sacred cosmos is neither apolitical nor disinterested in issues relevant to race relations. To the contrary, it contains a race-based ideological viewpoint that emphasizes structural explanations for and solutions to the problems of racial inequality."2 While white Americans, owing to their privileged structural location, are more likely to sacralize their nation as equitable and fair, and thus explain black-white inequality in terms of blacks' own supposed individual shortcomings (e.g., see Jones 2016; Perry, Whitehead, and Davis 2018), black Americans, Shelton and Emerson point out, are the most likely to view the sources of black-white inequality as primarily structural, owing to lack of educational opportunities or

\footnotetext{
2 This is not to say that scholars are unaware of considerable diversity among black American Christians with regard to their political engagement and views toward racial issues like affirmative action. On the contrary, Shelton and Cobb's (2018) analyses of black religious traditions has recently underscored this point. Rather, Shelton and Emerson's (2012) argument explicates the more generalized theological responses to the near-universal experience of black oppression in the United States.
} 
outright discrimination. Building on these insights, we turn to develop our empirical expectations.

\section{Summary and expectations}

Research consistently demonstrates that whites who more strongly conflate Christian and American identities also tend to draw sharper racial, ethno-religious, and national boundaries, suggesting that claims to a "Christian nation" are essentially about bolstering white supremacy (Gorski 2017b; McDaniel et al. 2011; Perry and Whitehead 2015a, 2015b). We propose that focusing on non-whites, and blacks specifically, is an ideal way to test that supposition. Finding that black Americans who view being Christian as essential to being American also hold dominant white-racial views would support the conclusion that white supremacy undergirds claims about America's Christian heritage and identity.

However, research also suggests that differential structural locations, primarily revolving around racial identity, may not only influence people's explanations of racial inequality, but how they link certain religious beliefs to those explanations (Collins 1986; Frost and Edgell 2017; Shelton and Emerson 2012). Structural privilege has historically led white Americans to defend the inherent righteousness and fairness of the United States, viewing their relative prosperity as earned and deserved. Thus, we anticipate that whites who conflate Christian and American identities will be less willing to blame systemic factors for black-white inequality, but will be more likely to fault blacks' supposed individual shortcomings. Conversely, the nexus of racial oppression and black religious experience has historically influenced black Americans to place a high value on racial justice and an emphasis on structural, policy-based changes as solutions to racial inequality (Cobb et al. 2015; Shelton and Emerson 2012). Consequently, we expect that black Americans who more strongly connect being an American with being a Christian will be 
more likely to favor explanations of racial inequality that are structural, and not those that blame blacks themselves.

\section{Methods}

\section{Data}

We use data from the 2014 wave of the General Social Survey available from the Association of Religion Data Archives (theARDA.com). The National Opinion Research Center (NORC) has conducted the GSS since 1972, and biennially since 1994. The personal-interview survey design and full-probability sampling method make it an ideal source for examining Americans' attitudes about racial issues. The 2014 GSS is also the most recent wave of the data that includes both our outcome variables and our independent variable of interest concerning the importance of being Christian to being "truly American." 3 The data in all analyses were weighted using WTSS. We chose to limit our analytic sample to only those respondents who identify as black (Non-Hispanic) and white (Non-Hispanic). All of the analyses presented below were also performed using an expanded set of racial categories. These included white (NonHispanic), black (Non-Hispanic), Hispanic, and other/multiple race. Only differences between white and black respondents were consistent across the dependent measures. For this reason, we chose to only focus on black and white respondents which allows us to highlight the differences between how white and black Americans interpret the relationship between Christianity, American-ness, and explanations for racial inequality.

\section{Measures}

\footnotetext{
${ }^{3}$ The 1996 GSS contains both these measures and including that data set (while controlling for year) did not substantively alter our findings. However, incorporating data nearly 20 years prior to the most recent data set presented an interpretive problem in that race relations have shifted in the past few decades. Because the findings are substantively the same, we have opted to focus on the most recent 2014 data to draw more relevant present-day conclusions.
} 


\section{Dependent variables}

To measure attitudes toward racial inequality, especially regarding black Americans, we use three related measures (for other studies using these measures, see Cobb 2014; Cobb et al. 2015; Emerson, Smith, and Sikkink 1999; Hinojosa and Park 2004; Hunt 2007; Shelton and Emerson 2012; Taylor and Merino 2011). Each begins with the prompt, "On the average African Americans have worse jobs, income and housing than white people," with another follow-up question after which respondents are asked to state either "Yes" or "No" to signal whether they agree or not. The first follow-up question asks, "Do you think these differences are mainly due to discrimination?" The second asks, "Do you think these differences are because most (Blacks/African-Americans) don't have the chance for education that it takes to rise out of poverty?" The final measure asks, "Do you think these differences are because most (Blacks/African-Americans) just don't have the motivation or willpower to pull themselves up out of poverty?" Throughout the rest of the analysis we refer to each of these measures as "Discrimination", "Education", and "Motivation", respectively.

As we might expect, the percentage of Americans who affirm these different explanations for racial inequality varies by race, particularly when it comes to recognizing discrimination as a key factor (see Table 1). While 29.5 percent of whites believe that discrimination is a reason for racial inequality, nearly twice as many (57.6 percent) black Americans affirm this explanation. Other explanations are more similar. For example, 40.6 percent of whites agree that lack of access to education explains racial inequality compared to 46.9 percent of blacks. And only slightly more blacks (48.2 percent) than whites (44.5 percent) believe that racial inequality is due

\footnotetext{
${ }^{4}$ The GSS also includes a fourth possible explanation where respondents could answer whether they think blackwhite inequality persists "Because most (Negroes/Blacks/African Americans) have less in-born ability to learn." Because so few Americans affirmed this option in 2014, we opted to focus on the other three explanations following precedent set in previous studies (see Cobb et al. 2015; Emerson et al. 1999).
} 
to black Americans lacking the sufficient motivation to overcome poverty, which is not a significant difference.

\section{[TABLE 1 ABOUT HERE]}

\section{Independent variables of interest}

Our first key independent variable concerns how important respondents believe being a Christian is to being "truly American." The full question wording asks: "Some people say the following things are important for being truly American. Others say they are not important. How important do you think each of the following is? To be a Christian." Possible response options include "Very Important", "Fairly Important", "Not Very Important", "Not Important at All”, and "Can't Choose." We recoded the measure so that all respondents who chose "Very Important" = 1 with all other response categories being coded as 0 . In ancillary analyses (not shown), we utilized the original 4-value measure and our findings were not substantively different from what we have presented below. However, by focusing our attention on those Americans who see being Christian as essential to being truly American, our binary measure allows us to better isolate those who embrace Christian nationalist ideals. Additionally, while a multi-item scale may be ideal here, our measure has been profitably used in similar studies gauging Americans' beliefs about Christianity’s connection with American identity (Byrne 2011; Shelton 2010; Sherkat and Lehman 2018; Straughn and Feld 2010; Whitehead and Scheitle 2018). In the Tables we simply call this measure "Christian Very Important," which in our analytic sample accounts for 28.2 percent of white respondents and 54 percent of black respondents (see Table 1$).^{5}$

\footnotetext{
${ }^{5}$ The 2014 GSS also includes six additional questions that similarly ask whether other things are important for being truly American (for a comprehensive analysis of these measures, see Bonikowski and DiMaggio 2016). In ancillary analyses we examined each of these other boundary markers of American identity predicted differential attitudes toward these various explanations of racial inequality. We also investigated whether each were in any way
} 
Our second independent variable of interest is the racial category within which respondents place themselves. As discussed above, we limit our analytic sample to black (NonHispanic) and white (Non-Hispanic) respondents. In our analyses we include a binary variable where white $=0$ and black $=1$. In our analytic sample 17.6 percent of respondents identify as black (Non-Hispanic).

Our final key independent variable is a cross-product interaction term for the Christian Very Important measure and identifying as black. This will allow us to test if the association between strongly believing Christianity is essential to being truly American and explanations for racial inequality differs for black Americans compared to white Americans.

\section{Control variables}

We include a variety of control variables in the multivariate models following previous research (e.g., Cobb et al. 2015; Emerson et al. 1999). Our socio-demographic measures include age $($ in years $)$, gender $(1=$ women $)$, marital status $(1=$ married $)$, education $($ Less than high school, high school graduate, some college, Bachelor's [contrast category], and post-graduate), income $(1=<\$ 1,000$ to $25=>\$ 149,999)$, political party (Democrat, Independent [contrast category], and Republican), region $(1=$ South $)$, and size of place $(1=$ rural $){ }^{6}$ Because we want to ensure that our variable Christian Very Important is not just a proxy for religious

moderated by respondents' race. Out of all six markers, there were only four instances where race significantly moderated their effect out of a total of 18 models. The lower-order effects for each marker were even more inconsistent. Furthermore, none of these boundary markers had a significant interaction for more than one of the three dependent variables. As we show below, the interaction between the Christianity Very Important marker and race is significant for two dependent variables, and marginally significant in the third. We conclude that while there are some scattered significant interactions, none are as consistent as what we show below. Lastly, while notable for empirical reasons, properly accounting for each different boundary marker theoretically is beyond the purview of the present analysis.

${ }^{6}$ Sikkink and Emerson (2008) identify a college degree as a key factor predicting whites' racial attitudes and thus we adopt that here by using Bachelor's degree as the contrast category. In the models that follow, we also examined a series of dichotomous variables for marital status (divorced, separated, widow, never married), region (Northeast, Midwest, West), and size of place (Urban, Suburb, Town). Using married, South, and rural as the contrast categories, there were no significant differences across these categories. Therefore, we include married, South, and rural as single variables for a more parsimonious model. 
conservatism, we include a number of religion controls as well. These include religious

affiliation (Evangelical Protestant, Mainline Protestant, Black Protestant [contrast category],

Catholic, Jewish, Other, Unaffiliated $){ }^{7}$ religious service attendance $(0=$ Never to $8=$ More than

once a week), and views about the Bible (Biblical literalist [contrast category], Bible is inspired, and Bible is a book of fables). ${ }^{8}$

\section{Plan of Analysis}

Because the response categories for each of the dependent variables are dichotomous, we use binary logistic regression as our model estimation procedure. In order to address missing data we employ multiple imputation (MI) techniques. ${ }^{9}$ Table 3 provides standardized coefficients for each variable in the model—which allows us to examine substantive significance alongside statistical significance - as well as odds ratios. These standardized coefficients are estimated as $B_{y x}^{*}=b_{y x}\left(s_{x} / s_{y}\right)$ and use Pampel's (2000) simplification of assuming that the standard deviation of $\operatorname{logit}(\mathrm{y})=1.8138$. We use the proportional reduction in error (PRE) statistic in order to appraise model fit. We calculate PRE as: Likelihood Ratio chi-square/-2 Log Likelihood Intercept Only. Each PRE score is the average of the PRE scores across all five imputation models. Finally, using the unstandardized estimates from our multivariate models (with all

\footnotetext{
${ }^{7}$ There are differences across religious traditions concerning the percent of adherents who believe Christianity is very important to being considered truly American. Evangelical Protestants (56.1 percent), Mainline Protestants (36.3 percent), Black Protestants (60.9 percent), Catholics (29.7 percent), Other faiths (19.2 percent), and the unaffiliated ( 8.3 percent) all differ in their support of this boundary marker. For this reason, it is important to control for religious tradition in the multivariate models. The fact that 19.2 percent of "Other" religious faiths and 8.3 percent of the unaffiliated affirm our measure is consistent with recent research suggesting "Christian nationalism" or preferences for "public religious expression" can transcend Christian faith traditions (see Braunstein and Taylor 2017; Delehanty et al. 2018; Stewart et al. 2018).

${ }^{8}$ In ancillary analyses (available upon request), we also examined triple interactions between Christian Very Important, race, and either religious service attendance and biblical literalism. There were no significant triple interactions for any of the dependent variables.

${ }^{9}$ The PROC MI procedure in SAS 9.3 generates five imputed datasets using multiple Markov Chains based on all variables included in the models, resulting in an overall $\mathrm{N}$ of $3060(612 \times 5)$. All analyses use these MI datasets. The results in Table 2 and those used to construct the figures in Figure 1 use the MI ANALYZE procedure in SAS. This procedure combines the results of all five imputations and generates overall estimates, standard errors, and significance tests.
} 
continuous measures centered), in Figure 1 we graphically display the interactions between racial identity and the Christian Very Important measure. We estimate predicted probabilities of agreeing that black Americans experience worse outcomes due to discrimination (Figure 1a), lack of access to education (Figure 1b), or lack of willpower (Figure 1c).

\section{Results}

Consistent with what we see in the percentage distributions in Table 1, bivariate correlations across our outcome measures (see Table 2) show that black Americans are significantly more likely than whites to agree that discrimination plays a key role in racial inequality $(r=.23 ; p<.001)$, but being black is not significantly associated with affirming other explanations for racial inequality. Moreover, Americans who believe that being Christian is very important to being truly American are significantly more likely to blame black Americans' lack of motivation or willpower for them being worse off $(r=.23 ; p<.001)$. Such Americans, however, are no different from other Americans in attributing racial inequality to blacks' lack of educational opportunities $(r=-.06 ; p=\mathrm{ns}$ ) or affirming discrimination as an explanation for racial inequality $(r=.04 ; p=\mathrm{ns})$. As the multivariate analyses will show below, however, these non-associations between Americans' explanations for racial inequality and Christianity’s connection to American civic belonging are due to stark racial differences.

\section{[TABLE 2 ABOUT HERE]}

In Table 3 we display results for each dependent variable including a model without the race and Christian Very Important interaction (Model 1) and a model with the interaction (Model 2). Because the primary focus of our prediction pertains to the interaction, we focus on Model 2 for each measure of agreement with different explanations for racial inequality. In the "Discrimination" Model 2 we find that the lower order effects for believing being Christian is 
very important to being truly American and identifying as black are both non-significant. However, the interaction between the Christian Very Important measure and identifying as black is significant and positive. The direction of this effect suggests that black Americans who strongly affirm the importance of Christianity for being truly American are significantly more likely than their white counterparts to attribute black-white racial inequality to discrimination.

In the "Education" Model 2 we find that neither the lower-order Christian Very Important measure or the lower-order black race measure are significantly associated with believing lack of access to education explains racial inequality. We do find that the interaction measure is marginally significant and positive, which, because of the smaller sample $(\mathrm{N}=612)$, we take to be a meaningful association. As with the "Discrimination" Model 2 interaction, here again we see that black Americans who affirm the importance of Christianity for being truly American are more likely than white Americans to explain black-white inequality in terms of blacks' relative lack of access to educational opportunities.

In our final Model 2 which predicts agreement that black Americans lack the "Motivation" to better their situation, we find that, while the lower-order race measure is nonsignificant as in the previous models, the lower-order Christian Very Important measure is significantly and positively associated $(\beta=.18 ; p<.01)$. Because this represents the conditional effect of "Christian Very Important" on affirming the motivation explanation when race $=0$ (i.e., whites), this means that white Americans who believe that being Christian is very important to being truly American are significantly more likely than other whites to believe that blacks are worse off than whites because they lack motivation. The race and Christian Very Important interaction term is negative and significant $(\beta=-.20 ; p<.05)$. Yet again, we find evidence that black Americans who hold strongly to the importance of being Christian to being truly American 
view racial inequality differently from white Americans who hold the same belief. In this case, blacks who affirm that being Christian is very important to being American are significantly less likely than their white counterparts to blame black-white inequality on blacks' supposed lack of motivation.

Figure 1 clearly illustrates how racial identity moderates the association between our Christian Very Important measure and explanations for racial inequality. The bars on the right side of Figures 1a-c show that for Americans who do not believe that being a Christian is very important to being truly American, racial identity makes little to no difference whatsoever in terms of affirming certain explanations for racial inequality. The difference, rather, is all in the bars on the left side of Figures 1a-c. Specifically, Figures 1a and 1b show that black Americans who believe being a Christian is very important to being truly American have a significantly higher predicted probability of agreement that the inequality black Americans experience is due to discrimination or lack of access to education. Notably, in these two figures, white Americans who affirm that being a Christian is very important to being truly American do not differ in their racial inequality explanations from their white counterparts who do not affirm a connection between Christian and American identities. Conversely, in Figure 1c, whites who believe being a Christian is very important to being truly American are significantly more likely to agree that black Americans lack the willpower to pull themselves out of poverty compared to other whites who do not affirm that link between Christianity and America. And for black Americans, we see the opposite. Those who believe being a Christian is very important to being a truly American are much less likely to believe that racial inequality is due to black Americans lacking the motivation or willpower to improve their standing.

[TABLE 3 AND FIGURE 1 ABOUT HERE] 


\section{Discussion}

While numerous studies suggest that white Americans who draw a close connection between Christian and American group boundaries tend to hold attitudes that bolster white racial dominance and separatism, no studies to date have explored whether this identity conflation may have the same influence on the racial views of non-whites. Drawing on a representative sample of black and white Americans, and focusing on explanations of racial inequality as our outcome, our findings demonstrate conflicting trends across race. As we would expect, white Americans who viewed being a Christian as very important to being truly American are more likely (compared to both blacks and other whites) to blame blacks' supposed lack of motivation for black-white inequality, a view that fits squarely within a dominant white-racial frame that explains whites' successes in meritocratic, colorblind terms (Bonilla-Silva 2009; Cobb et al. 2015; Feagin 2013; Frost and Edgell 2017; Shelton and Emerson 2012). In contrast, however, we found that black Americans who affirmed being a Christian was very important to being truly American were more likely to attribute black-white inequality to racial discrimination and educational opportunities, and are less likely to explain inequality in terms of blacks' own supposed lack of motivation. These findings suggest that connecting Christian and American identities does not necessarily bolster white supremacy, but for black Americans it may in fact evoke ideals of racial justice and structural transformation.

Before further discussion of the implications of this research, some data limitations are worth addressing in order to chart a path for future research. Clearly, these data are crosssectional and thus we cannot definitively determine causal direction. While we would argue that the directional model we propose (beliefs that conflate Christian and American identity influence racial attitudes) make the most theoretical sense and have precedent in previous literature (e.g., 
Davis 2018a; McDaniel et al. 2011; Perry and Whitehead 2015a, 2015b; Perry et al., 2018), longitudinal or experimental studies would be required to definitively determine causality. Qualitative interviews might also be useful to flesh out the thought processes of black and white Americans regarding the issues of religion, national identity, and racial inequality. We also acknowledge that our analysis is limited to a single-item measure tapping respondents' views about Christianity's relationship to being an American. Other studies have used multi-item scales to measure what they call "Christian nationalism" (Davis 2018a, 2018b; McDaniel et al. 2011; Merino 2010; Perry and Whitehead 2015a, 2015b; Shortle and Gaddie 2015; Whitehead et al. 2018) and we believe that multi-item measures would be ideal. Nevertheless, the GSS is useful in that it provides a sufficient sample size of non-white Americans and provides tested measures of Americans' racial inequality attitudes (Cobb 2014; Cobb et al. 2015; Emerson et al. 1999; Hunt 2007; Shelton and Emerson 2012; Taylor and Merino 2011).

Lastly, while the GSS does include a wide variety of control measures to help us isolate the independent and interrelated influences of our Christian-American identity measure and race on racial attitudes, we acknowledge significant variance is left unexplained in our models and there is always potential for omitted variable bias. In particular, we are unable to account for personality characteristics like "social dominance orientation" or "right-wing authoritarianism," which have been shown to predict explanations of racial inequality (Pratto et al. 1994). We are also unable to account for significant interracial contact (for example, the extent to which a respondent was imbedded within a multiracial or same-race congregation), which could also shape Americans' attitudes toward racial issues (Cobb et al. 2015; Perry 2013, 2014). While we contend that our findings are robust to important covariates, future studies would ideally account for confounders we are unable to include. 
Despite these limitations, our findings extend our understanding of race and its intersection with religion and nationalism in several important ways. Most prominently, black Americans who see American identity as fundamentally Christian in some sense actually hold the most "structural" and least "individualist" interpretations of racial inequality, more so even than black Americans who do not connect being American to being Christian. This would support our earlier theory that black Americans may reinterpret the relationship between religion and nation differently from the way whites have historically, such that black Americans understand America's obligations as a "Christian nation" as dismantling racist structures and not blaming the victims of racial injustice. In contrast, drawing a closer connection between Christian and American identities did not seem to influence the racial attitudes of whites on two out of the three explanations for racial inequality (discrimination and educational opportunities). At the very least, this suggests that beliefs about systemic or structural racial inequality are no more settled among whites who strongly conflate Christian and American identities than it is for other white Americans. However, it is unclear whether these non-effects are due primarily to a lack of influence of Christian nationalist ideology among whites regarding structural explanations for inequality, or whether white Americans are already on the whole so strongly disinclined to accept such answers that their beliefs about America's Christian identity does not influence this outcome much. By contrast, it was only regarding the belief that blacks lack sufficient motivation for which conflating Christian and American identities seemed to correspond with whites' more critical attitudes toward blacks themselves. This may indicate that, for white Americans, connecting America with Christianity bolsters an ideology of rugged individualism and pulling oneself up by their bootstraps that casts black Americans as outsiders 
who lack the willpower to improve their situation (see Cobb et al. 2015; Emerson et al. 1999; Shelton and Emerson 2012).

Interestingly, while previous research using earlier waves of the GSS has found that whites and blacks tend to affirm different explanations for black-white inequality (e.g., Cobb et al. 2015; Hunt 2007) our biviarate and multivariate analyses using 2014 data showed that blacks were only more likely to affirm discrimination as the reason for black-white inequality compared to whites. In contrast, blacks did not differ significantly from whites in believing that educational opportunities or motivation explained racial inequality until they were parceled out by whether they affirmed Christianity's connection to American identity. This suggests that black Americans in general may no longer differ greatly from whites in general in terms of their explanations for racial inequality. But black Americans who ascribe a closer connection between America and Christianity may recognize a wider gulf between the Christianity they envision and the dominant white racial ideologies that undergird America's racial caste system (Shelton and Emerson 2012). Future research could examine the intersection of religious and national identities with race over time in order to establish whether significant shifts have indeed occurred.

Finally, this analysis helps to fill a gap in the burgeoning literature on Christian nationalism. Previous research on overlapping Christian and national identities and their influence on various social attitudes focused on white Americans alone (e.g., Davis 2018b; Perry and Whitehead 2015a, 2015b) or controlled for race in multivariate models (e.g., Davis 2018a; Perry et al. 2018; Sherkat and Lehman 2018; Stewart, Edgell, and Delehanty 2018). Such modeling assumes that the association between Christian nationalism and various outcome measures is uniform across racial and ethnic groups. The present study begins the process of documenting that the influence of the intersection of religious and national identities is indeed 
not uniform across subgroups, especially race. This is further evidence that the intersection of religious and national identities does appear to be flexible, malleable, and responsive to particular social locations and standpoints (Bean 2014; Whitehead et al. 2018). These findings also answer recent calls for intersectional analyses of the overlap of race, religion, and political/social attitudes (Edgell 2017; Frost and Edgell 2017). Essentially, Christian-American identity is raced, intersectional, and varies in how it is interpreted and used. It is important that scholars interested in the association between religio-national identities and various social attitudes and behaviors assess whether these associations vary by respondents' structural location, like race and ethnicity.

\section{Conclusion}

It is safe to assume that, in Trump's America, appeals for the nation to "return" to its supposed Christian heritage will not dissipate. Indeed, such calls played an integral role in garnering votes that ultimately handed Trump the presidency (Sides 2017; Whitehead et al. 2018). Prior research demonstrates that consistently identifying being American with being Christian tends to activate a particular sector of society to constrain the boundaries of ethnonational group membership. Many assume that this is exactly why Trump uses Christian nationalist rhetoric. However, using recent nationally representative data, this analysis establishes that identifying being Christian with being American does not operate uniformly across racial groups. Focusing on explanations of racial inequality in particular, black Americans who believe being Christian is very important to being truly American, given their differences in structural location, are much more likely to attribute racial inequality to structural issues rather than individual shortcomings. Unlike their white counterparts, for black Americans, closely overlapping national and religious identities does not bolster white supremacy, but rather 
challenges racist structures and victim-blaming. Given that these data were collected in 2014, before Trump was elected, it very well could be that his reliance on "Christian nation" language might moderate the relationships documented above. In fact, given his (at times) explicit support for white nationalist talking points, Trump's use of Christian nationalism could result in black Americans who view being Christian as central to being American to become even more supportive of structural explanations of racial injustice. Therefore, it will be important to monitor the relationships between attitudes toward racial injustice and "Christian nation" ideology across racial groups throughout the remainder of the Trump presidency and beyond. 


\section{References}

Aho, James. 2013. "Christian Heroism and the Reconstruction of America." Critical Sociology 39(4):545-560.

Alexander, Michelle. 2012. The New Jim Crow: Mass Incarceration in the Age of Colorblindness. New York: The New Press.

Barnes, Sandra. 2005. "Black Church Culture and Community Action.” Social Forces 84:967994.

Bean, Lydia. 2014. The Politics of Evangelical Identity: Local Churches and Partisan Divides in the United States and Canada. Princeton, NJ: Princeton University Press.

Berger, Peter. 1967. The Sacred Canopy: Elements of a Sociological Theory of Religion. New York: Doubleday.

Bonikowski, Bart, and Paul DiMaggio. 2016. "Varieties of American Popular Nationalism." American Sociological Review 81:949-80.

Bonilla-Silva, Eduardo. 2009. Racism Without Racists: Color-Blind Racism and the Persistence of Racial Inequality in America. Third Edition. New York: Roman \& Littlefield.

Braunstein. Ruth. 2017. "Muslims as Outsiders, Enemies, and Others: The 2016 Presidential Election and the Politics of Religious Exclusion.” American Journal of Cultural Sociology 5(3):355-372.

Braunstein, Ruth. 2018. “A (More) Perfect Union? Religion, Politics, and Competing Stories of America.” Sociology of Religion 79(2):172-195.

Braunstein, Ruth, and Malaena Taylor. 2017. 'Is the Tea Party a 'Religious' Movement? Religiosity in the Tea Party Versus the Religious Right.” Sociology of Religion 78(1):3359.

Brown, R. Khari. 2009. "Racial/Ethnic Differences in the Political Behavior of American 
Religious Congregations.” Sociological Spectrum 29(2):227-248.

Byrne, Jennifer. 2011. "National Identity and Attitudes toward Immigrants in a 'Multicreedal' America." Politics \& Policy 39(4):485-414.

Calhoun-Brown, Allison. 1999. "The Image of God: Black Theology and Racial Empowerment in the African American Community." Review of Religious Research 40(3):197-212.

C-Span. 2016a. "Donald Trump Remarks in Orlando, Florida." Video Posted by C-Span. August 11. Accessed at: https://www.c-span.org/video/?413877-1/donald-trump-addressesevangelical-leaders-orlando-florida

C-Span. 2016b. "Presidential Candidate Donald Trump at Liberty University." Video Posted by C-Span. January 18. Accessed at: https://www.c-span.org/video/?403331-1/donaldtrump-remarks-liberty-university.

Cherry, Conrad. 1998. God's New Israel: Religious Interpretations of American Destiny. Chapel Hill, NC: University of North Carolina Press.

Cleage, Albert B. Jr. 1972. Black Christian Nationalism: New Directions for the Black Church. New York: W. Morrow.

Cobb, Ryon J. 2014. "Still Divided by Faith? Evangelical Religion and the Problem of Race in America, 1977-2010.” Pp. 128-41 in Christians and the Color Line: Race and Religion after Divided by Faith, edited by R. J. Hawkins and P.L. Sinitiere. New York: Oxford University Press.

Cobb, Ryon J., Samuel L. Perry, and Kevin D. Dougherty. 2015. “United by Faith? Race/Ethnicity, Congregational Diversity, and Explanations of Racial Inequality.” Sociology of Religion 76(2):177-198.

Cone, James H. 1969. Black Theology and Black Power. San Francisco, CA: Harper \& Row. 
Cone, James H. 1997. God of the Oppressed. New Revised Edition. Maryknoll, NY: Orbis.

Davis, Joshua T. 2018a. "Enforcing Christian Nationalism: Examining the Link Between Group Identity and Punitive Attitudes in the United States." Journal for the Scientific Study of Religion 57(2):300-317.

Davis, Joshua T. 2018b. "Funding God's Policies, Defending Whiteness: Christian Nationalism and Whites' Attitudes towards Racially-Coded Government Spending." Ethnic and Racial Studies. doi: 10.1080/01419870.2018.1527939

Delehanty, Jack, Penny, Edgell, and Evan Stewart. 2017. “Christian America? Secularized Evangelical Discourses and the Boundaries of National Belonging.” Paper Presented at the American Sociological Association Annual Meeting, August 14, Montreal, Quebec, Canada.

Douglass, Frederick. 1845. Narrative of the Life of Frederick Douglass. E-Book accessed at: https://www.ibiblio.org/ebooks/Douglass/Narrative/Douglass_Narrative.pdf.

Edgell, Penny. 2017. “An Agenda for Research on American Religion in Light of the 2016 Election.” Sociology of Religion 78(1):1-8.

Edgell, Penny, and Eric Tranby. 2010. "Shared Visions? Diversity and Cultural Membership in American Life.” Social Problems 57(2):175-204.

Edwards, Korie, Brad Christerson, and Michael O. Emerson. 2012. "Race, Religious Organizations, and Integration.” Annual Review of Sociology 39:211-228.

Emerson, Michael O., Elizabeth Korver-Glenn, and Kiara W. Douds. 2015. Studying Race and Religion: A Critical Assessment.” Sociology of Race and Ethnicity 1(3):349-359.

Emerson, Michael O., Christian Smith, and David Sikkink. 1999. "Equal in Christ, but Not in the World: White Conservative Protestants and Explanations of Black-White Inequality." 
Social Problems 46(3):398-417.

Feagin, Joe R. 2013. The White Racial Frame: Centuries of Racial Framing and CounterFraming. Second Edition. New York: Routledge.

Frost, Jacqui, and Penny Edgell. 2017. “Distinctiveness Reconsidered: Religiosity, Structural Location, and Understandings of Racial Inequality." Journal for the Scientific Study of Religion 56(2):277-301.

Goldberg, Michelle. 2006. Kingdom Coming: The Rise of Christian Nationalism. New York. W. W. Norton \& Company.

Gorski, Philip. 2017a. American Covenant: A History of Civil Religion from the Puritans to the Present. Princeton, NJ: Princeton University Press.

Gorski, Philip. 2017b. "Why Evangelicals Voted for Trump: A Critical Cultural Sociology." American Journal of Cultural Sociology 5(3):338-354.

Harris, Fredrick C. 1999. Something Within: Religion in African-American Political Activism. New York: Oxford University Press.

Hinojosa, Victor J., and Jerry Z. Park. 2004. "Religion and the Paradox of Racial Inequality Attitudes.” Journal for the Scientific Study of Religion 43(2):229-238.

Hunt, Matthew O. 2007. “African American, Hispanic, and White Beliefs about Black/White Racial Inequality, 1977-2004.” American Sociological Review 72(3):390-415.

Jones, Robert P. 2016. The End of White Christian America. New York, NY: Simon \& Schuster. Justice, Jessilyn, and Taylor Berglund. 2016. “Trump, Palin Challenge ORU Students to Launch "Great Awakening."' Charisma News. January 20. Accessed at: https://www.charismanews.com/politics/54595-trump-palin-challenge-oru-students-tolaunch-great-awakening 
King, Martin Luther, Jr. 1956. "Paul's Letter to American Christians.” Delivered at Dexter Avenue Baptist Church, Montgomery, Alabama. November 4. Accessed at: https://kinginstitute.stanford.edu/king-papers/publications/knock-midnight-inspirationgreat-sermons-reverend-martin-luther-king-jr-1.

King, Martin Luther, Jr. 1963. “Letter From a Birmingham Jail.” Accessed at: https://www.africa.upenn.edu/Articles_Gen/Letter_Birmingham.html

Lincoln, C. Eric, and Lawrence H. Mamiya. 1990. The Black Church in the African American Experience. Durham, NC: Duke University Press.

Marx, Karl. [1844] 1967. “Toward a Critique of Hegel's Philosophy of Right.” Pp. 63-74 in Karl Marx: Selected Writings, edited by David McLellen. New York: Oxford University Press.

McDaniel, Eric L., Irfan Nooruddin, Allyson Faith Shortle. 2011. "Divine Boundaries: How Religion Shapes Citizens' Attitudes toward Immigrants." American Politics Research 39(1):205-233.

McDaniel Eric L., Irfan Nooruddin, Allyson Faith Shortle. 2016. "Proud to be an American? The Changing Relationship of National Pride and Identity.” The Journal of Race, Ethnicity, and Politics 1(1):145-76.

Merino, Stephen M. 2010. “Religious Diversity in a 'Christian Nation': The Effects of Theological Exclusivity and Interreligious Contact on the Acceptance of Religious Diversity." Journal for the Scientific Study of Religion 49(2):231-246.

Morris, Aldon D. The Origins of the Civil Rights Movement: Black Communities Organizing for Change. New York: The Free Press.

Pampel, Fred C. 2000. Logistic Regression: A Primer. Thousand Oaks, CA: Sage Publications. Paris, Peter J. 1985. The Social Teaching of the Black Churches. Philadelphia, PA: Fortress. 
Perry, Samuel L. 2013. “Religion and Whites’ Attitudes toward Interracial Marriage with African Americans, Asians, and Latinos.” Journal for the Scientific Study of Religion $52(2): 425-442$.

Perry, Samuel L. 2014. "Hoping for a Godly (White) Family: How Desire for Religious Heritage Affects Whites’ Attitudes toward Interracial Marriage.” Journal for the Scientific Study of Religion 53(1):202-218.

Perry, Samuel L., and Andrew L. Whitehead. 2015a. "Christian Nationalism and White Racial Boundaries: Examining Whites’ Opposition to Interracial Marriage.” Ethnic and Racial Studies 38(10):1671-1689.

Perry, Samuel L., and Andrew L. Whitehead. 2015b. "Christian Nationalism, Racial Separatism, and Family Formation: Attitudes toward Transracial Adoption as a Test Case.” Race and Social Problems 7(2):123-134.

Perry, Samuel L., Andrew L. Whitehead, and Joshua T. Davis. 2018. “God's Country in Black and Blue: How Christian Nationalism Shapes Americans' Views about Police (Mis)treatment of Blacks." Sociology of Race and Ethnicity. doi:

$10.1177 / 2332649218790983$

Pratto, Felicia, James Sidanius, Lisa M. Stallworth, and Bertram F. Malle. 1994. “Social Dominance Orientation: A Personality Variable Predicting Social and Political Attitudes." Journal of Personality and Social Psychology 67(4):741-763.

Shelton, Jason E. 2010. “E Pluribus Unam? How Racial, Ethnic, and Religious Group Memberships Impact Beliefs about American National Identity." Nationalism and Ethnic Politics 16(1):67-91.

Shelton, Jason E., and Ryon J. Cobb. 2018. "Black Reltrad: Measuring Religious Diversity and 
Commonality Among African Americans.” Journal for the Scientific Study of Religion 56(4):737-764.

Shelton, Jason E., and Michael O. Emerson. 2012. Blacks and Whites in Christian America: How Racial Discrimination Shapes Religious Convictions. New York: NYU Press.

Sherkat, Darren E., and Derek Lehman. 2018. "Bad Samaritans: Religion and Anti-Immigrant and Anti-Muslim Sentiment in the United States.” Social Science Quarterly 99(5):17911804.

Shortle, Allyson F., and Ronald Keith Gaddie. 2015. "Religious Nationalism and Perceptions of Muslims and Islam.” Politics and Religion 8:435-457.

Sides, John. 2017. "Race, Religion, and Immigration in 2016: How the Debate over American Identity Shaped the Election and What It Means for a Trump Presidency." A Research Report from the Democracy Fund Voter Study Group. Accessed at:

\section{file:///C:/Users/admin/Downloads/RaceReligionImmigration_2017june12.pdf}

Sikkink, David, and Michael O. Emerson. 2008. "School Choice and Racial Segregation in US Schools: The Role of Parents' Education.” Ethnic and Racial Studies 31(2):267-293.

Stewart, Evan. 2018. "Public Religion and the Vote for Donald Trump: Evidence from Panel Data." Paper Presented at the American Sociological Association Annual Conference in Philadelphia, PA.

Stewart, Evan, Penny Edgell, and Jack Delehanty. 2018. “The Politics of Religious Prejudice and Tolerance for Cultural Others.” The Sociological Quarterly 59(1):17-39.

Straughn, Jeremy Brooke, and Scott L. Feld. 2010. “America as a 'Christian Nation'? Understanding Religious Boundaries of National Identity in the United States.” Sociology of Religion 71(3):280-306. 
Taylor, Marylee C, and Stephen M. Merino. 2011. "Race, Religion, and Beliefs about Racial Inequality." Annals of the American Academy of Political and Social Science 634(1):6077.

Weber, Max. [1922] 1993. The Sociology of Religion. Boston, MA: Beacon Press.

Whitehead, Andrew L., Samuel L. Perry, and Joseph O. Baker. 2018. "Make America Christian Again: Christian Nationalism and Voting for Donald Trump in the 2016 Presidential Election." Sociology of Religion 79(2):147-171.

Whitehead, Andrew L., and Christopher P. Scheitle. 2018. "We the (Christian) People:

Christianity and American Identity from 1996 to 2014. Social Currents 5(2):157-172.

Williams, Rhy H. 2013. "Civil Religion and the Cultural Politics of National Identity in Obama's America.” Journal for the Scientific Study of Religion 52(2):239-257.

Wilmore, Gayraud S. 1973. Black Religion and Black Radicalism: An Interpretation of Religious History of African Americans. Garden City, NJ: Anchor/Doubleday. 
Table 1: Descriptive Statistics of Analytical Sample (Black Non-Hispanic \& White Non-Hispanic Only), White Non-Hispanic, and Black Non-Hispanic

\begin{tabular}{|c|c|c|c|c|c|c|c|}
\hline & \multirow[b]{2}{*}{ Description } & \multicolumn{2}{|c|}{$\begin{array}{c}\text { Analytic } \\
\text { Sample } \\
(\mathrm{N}=612) \\
\end{array}$} & \multicolumn{2}{|c|}{$\begin{array}{l}\text { White Only } \\
(\mathrm{N}=496)\end{array}$} & \multicolumn{2}{|c|}{$\begin{array}{l}\text { Black Only } \\
(\mathrm{N}=116)\end{array}$} \\
\hline & & $\begin{array}{l}\% \text { or } \\
\text { Mean }\end{array}$ & SD & $\begin{array}{l}\% \text { or } \\
\text { Mean }\end{array}$ & SD & $\begin{array}{l}\% \text { or } \\
\text { Mean }\end{array}$ & SD \\
\hline Discrimination & $1=$ Yes & 34.5 & --- & 29.5 & --- & 57.6 & --- \\
\hline Education & $1=$ Yes & 41.7 & --- & 40.6 & --- & 46.9 & --- \\
\hline Willpower & $1=$ Yes & 45.2 & --- & 44.5 & --- & 48.2 & --- \\
\hline $\begin{array}{l}\text { Christian Very } \\
\text { Important }\end{array}$ & $\begin{array}{l}1=\text { Being Christian is Very } \\
\text { Important to be True American }\end{array}$ & 32.8 & --- & 28.2 & --- & 54.0 & --- \\
\hline Black & $1=$ Black & 17.6 & --- & --- & --- & --- & --- \\
\hline Age & In years & 50.5 & 17.5 & 51.5 & 17.8 & 45.6 & 15.8 \\
\hline Women & $1=$ Women & 55.5 & --- & 53.1 & --- & 66.3 & --- \\
\hline Married & $1=$ Married & 51.3 & --- & 57.2 & --- & 23.8 & --- \\
\hline Less than HS & $1=$ Less than High School & 10.3 & --- & 8.8 & --- & 16.8 & --- \\
\hline HS Graduate & $1=$ High School Grad & 24.8 & --- & 24.0 & --- & 28.8 & --- \\
\hline Some College & $\begin{array}{l}1=1-3 \text { Years of } \\
\text { College/Vocational }\end{array}$ & 28.5 & --- & 28.6 & --- & 33.8 & --- \\
\hline Bachelor's & $1=$ Bachelor's & 18.6 & --- & 20.3 & --- & 10.2 & --- \\
\hline Post-graduate & 1 = Post-graduate & 16.8 & --- & 18.2 & --- & 10.4 & --- \\
\hline Income & $1=\langle \$ 1 \mathrm{k}$ to $25=>\$ 149,999$ & 18.2 & 5.2 & 18.8 & 5.0 & 15.5 & 5.5 \\
\hline South & $1=$ Live in South & 39.8 & --- & 35.0 & --- & 62.3 & --- \\
\hline Rural & $1=$ Live in Rural Area & 13.0 & --- & 14.2 & --- & 7.7 & --- \\
\hline Democrat & $1=$ Democrat & 41.5 & --- & 34.5 & --- & 74.3 & --- \\
\hline Independent & 1 = Independent & 16.4 & --- & 17.3 & --- & 12.1 & --- \\
\hline Republican & 1 = Republican & 38.8 & --- & 44.9 & --- & 10.3 & --- \\
\hline Evangelical & $1=$ Evangelical & 26.1 & --- & 27.2 & --- & 21.1 & --- \\
\hline Mainline & 1 = Mainline & 16.6 & --- & 18.5 & --- & 7.3 & --- \\
\hline $\begin{array}{l}\text { Black } \\
\text { Protestant }\end{array}$ & $1=$ Black Protestant & 8.0 & --- & --- & --- & 42.6 & --- \\
\hline Catholic & 1 = Catholic & 21.2 & --- & 24.6 & --- & 5.2 & --- \\
\hline Jewish & 1 = Jewish & 2.2 & --- & 2.5 & --- & .9 & --- \\
\hline Other & $1=$ Other & 4.6 & --- & 5.1 & --- & 2.4 & --- \\
\hline Unaffiliated & $1=$ Unaffiliated & 21.1 & --- & 21.3 & --- & 20.3 & --- \\
\hline $\begin{array}{l}\text { Religious } \\
\text { service } \\
\text { attendance }\end{array}$ & $\begin{array}{l}0=\text { Never to } 8=\text { More than } \\
\text { once a week }\end{array}$ & 3.6 & 2.8 & 3.4 & 2.8 & 4.4 & 2.5 \\
\hline $\begin{array}{l}\text { Biblical } \\
\text { Literalist }\end{array}$ & $1=$ Biblical literalist & 31.6 & --- & 26.3 & --- & 56.0 & --- \\
\hline Bible Inspired & $1=$ Bible Inspired & 46.7 & --- & 50.5 & --- & 29.0 & --- \\
\hline Bible Fables & $1=$ Bible Fables & 21.4 & --- & 22.7 & --- & 15.4 & --- \\
\hline
\end{tabular}

Source: 2014 GSS (Weighted MI Data) 
Table 2: Correlations of Variables of Interest

\begin{tabular}{|c|c|c|c|}
\hline & Discrimination & Education & Motivation \\
\hline Christian Very Important & .05 & -.06 & $.23 * * *$ \\
\hline Black & $.23 * * *$ & .05 & .03 \\
\hline Age & -.00 & -.03 & $.13 * *$ \\
\hline Women & .03 & -.05 & $.09 *$ \\
\hline Married & $-.11 *$ & -.03 & -.06 \\
\hline Less than HS & $.11 * *$ & -.04 & $.14 * * *$ \\
\hline HS Graduate & $-.10^{*}$ & $-.10^{*}$ & .03 \\
\hline Some College & -.01 & $-.14 * * *$ & $.08 \dagger$ \\
\hline Bachelor's & .01 & $.16^{* * *}$ & $-.14 * *$ \\
\hline Post-graduate & .03 & $.15^{* * *}$ & $-.10 *$ \\
\hline Income & $-.11 *$ & -.02 & $-.10 *$ \\
\hline South & -.06 & $-13 * *$ & $.16^{* * *}$ \\
\hline Rural & -.02 & $-.12 * *$ & .02 \\
\hline Democrat & $.25 * * *$ & $.16^{* * *}$ & $-.10 *$ \\
\hline Independent & .02 & -.04 & $-.07 \dagger$ \\
\hline Republican & $-.27 * * *$ & $-.13 * *$ & $.15^{* * *}$ \\
\hline Evangelical & $-.08 \dagger$ & $-.08 \dagger$ & $.15^{* * *}$ \\
\hline Mainline & -.01 & -.02 & .00 \\
\hline Black Protestant & $.11^{*}$ & .00 & .02 \\
\hline Catholic & $-.07 \dagger$ & $-.08 \dagger$ & -.02 \\
\hline Jewish & -.02 & $.10 *$ & -.06 \\
\hline Other & .05 & $.11 * *$ & -.05 \\
\hline Unaffiliated & $.09 *$ & $.10^{*}$ & $-.10 *$ \\
\hline Religious service attendance & -.03 & -.03 & $.14 * * *$ \\
\hline Biblical Literalist & $-.07 \dagger$ & $-.17 * * *$ & $.19 * * *$ \\
\hline Bible Inspired & .00 & .06 & $-.08 \dagger$ \\
\hline Bible Fables & $.08 \dagger$ & $.11^{* *}$ & $-.12 * *$ \\
\hline
\end{tabular}

Source: 2014 GSS (Weighted MI Data); N = 612

$\dagger \mathrm{p}<.10 ; * \mathrm{p}<.05 ; * * \mathrm{p}<.01 ; * * * \mathrm{p}<.001$ 
Table 3: Logistic Regression of Non-Hispanic Black and Non-Hispanic White Americans' Attitudes toward Racial Inequality

\begin{tabular}{|c|c|c|c|c|c|c|c|c|c|c|c|c|}
\hline & \multicolumn{4}{|c|}{ Discrimination } & \multicolumn{4}{|c|}{ Education } & \multicolumn{4}{|c|}{ Motivation } \\
\hline & \multicolumn{2}{|c|}{ Model 1} & \multicolumn{2}{|c|}{ Model 2} & \multicolumn{2}{|c|}{ Model 1} & \multicolumn{2}{|c|}{ Model 2} & \multicolumn{2}{|c|}{ Model 1} & \multicolumn{2}{|c|}{ Model 2} \\
\hline & $\beta$ & OR & $\beta$ & OR & $\beta$ & OR & $\beta$ & OR & $\beta$ & OR & $\beta$ & OR \\
\hline Christian Very Important (CVI) & $.13 \dagger$ & 1.66 & .05 & $\begin{array}{ll}-- \\
--\end{array}$ & .08 & --- & .01 & --- & .10 & $\begin{array}{ll}-- \\
--\end{array}$ & $.18^{* *}$ & 2.05 \\
\hline CVI*Black & --- & --- & $.18^{*}$ & 3.05 & --- & --- & $.16 \dagger$ & 2.66 & --- & --- & $-.20 *$ & .28 \\
\hline Black & $.23 * *$ & 3.01 & .13 & --- & .08 & --- & -.01 & --- & -.01 & --- & .11 & --- \\
\hline Age & .05 & --- & .06 & --- & .00 & --- & .01 & --- & .08 & --- & .07 & --- \\
\hline Women & .01 & --- & .01 & --- & -.04 & --- & -.05 & --- & .08 & --- & .08 & --- \\
\hline Married & -.04 & --- & -.03 & --- & -.02 & --- & -.01 & --- & -.05 & --- & -.06 & --- \\
\hline Less than HS & .05 & --- & .05 & --- & $-.21 * *$ & .27 & $-.22 * *$ & .27 & $.22 * *$ & 3.76 & $.22 * *$ & 3.80 \\
\hline HS Graduate & $-.17 *$ & .48 & $-.16^{*}$ & .51 & $-.32 * * *$ & .25 & $-.31 * * *$ & .26 & $.15 \dagger$ & 1.89 & $.14 \dagger$ & 1.78 \\
\hline Some College & -.08 & --- & -.07 & --- & $-.36 * * *$ & .23 & $-.36^{* * *}$ & .24 & $.19 * *$ & 2.19 & $.19 * *$ & 2.15 \\
\hline Post-graduate & .00 & --- & .00 & --- & -.04 & --- & -.04 & --- & .03 & --- & .03 & --- \\
\hline Income & -.08 & --- & -.09 & --- & $-.17 *$ & .94 & $-.17 *$ & .94 & .01 & --- & .01 & --- \\
\hline South & $-.11 \dagger$ & .67 & $-.11 \dagger$ & .66 & $-.12 *$ & .65 & $-.12 *$ & .64 & .09 & --- & .09 & --- \\
\hline Rural & .02 & --- & .02 & --- & $-.11 \dagger$ & .55 & $-.11 \dagger$ & .56 & -.05 & --- & -.06 & --- \\
\hline Democrat & .08 & --- & .07 & --- & $.17 *$ & 1.86 & $.16^{*}$ & 1.84 & -.02 & --- & -.01 & --- \\
\hline Republican & $-.21 * *$ & .46 & $-.21 * *$ & .45 & .02 & --- & .02 & --- & $.13 \dagger$ & 1.62 & $.13 \dagger$ & 1.64 \\
\hline Evangelical & .05 & --- & .08 & --- & .04 & --- & .06 & --- & .12 & --- & .09 & --- \\
\hline Mainline & .07 & --- & .09 & --- & .03 & --- & .04 & --- & .06 & --- & .04 & --- \\
\hline Catholic & -.02 & --- & .00 & --- & -.09 & --- & -.08 & --- & .11 & --- & .10 & --- \\
\hline Jewish & .01 & --- & .02 & --- & $.14 \uparrow$ & 5.48 & $.14^{*}$ & 5.85 & -.04 & --- & -.05 & --- \\
\hline Other & .09 & --- & .09 & --- & $.16^{*}$ & 4.09 & $.17 *$ & 4.29 & .00 & --- & -.01 & --- \\
\hline Unaffiliated & .12 & --- & .14 & --- & .10 & --- & .11 & --- & .09 & --- & .07 & --- \\
\hline Religious service attendance & .04 & --- & .04 & --- & .05 & --- & .05 & --- & .05 & --- & .05 & --- \\
\hline Bible Inspired & $.18^{*}$ & 1.97 & $.18^{*}$ & 1.97 & $.22 * *$ & 2.28 & $.22 * *$ & 2.28 & -.09 & --- & -.09 & --- \\
\hline Bible Fables & $.18^{*}$ & 2.21 & $.17 *$ & 2.13 & $.21 *$ & 2.58 & $.21^{*}$ & 2.52 & -.08 & --- & -.07 & --- \\
\hline Intercept & -1.06 & & -1.14 & & .65 & & .59 & & $-1.95 *$ & & $-1.92 *$ & \\
\hline $\mathrm{N}$ & 612 & & 612 & & 612 & & 612 & & 612 & & 612 & \\
\hline PRE & .126 & & .133 & & .136 & & .141 & & .100 & & .108 & \\
\hline
\end{tabular}

Note: 2014 GSS (Weighted MI Data); Bachelor's, Black Protestant, Biblical literalist, and Independent are contrast categories $\dagger \mathrm{p}<.10 ; * \mathrm{p}<.05 ; * * \mathrm{p}<.01 ; * * * \mathrm{p}<.001$ 
Figure 1: Array of Interaction Effects of Race and Importance of being Christian to being an American on Attitudes toward Racial Inequality (continuous variables in each model are centered)

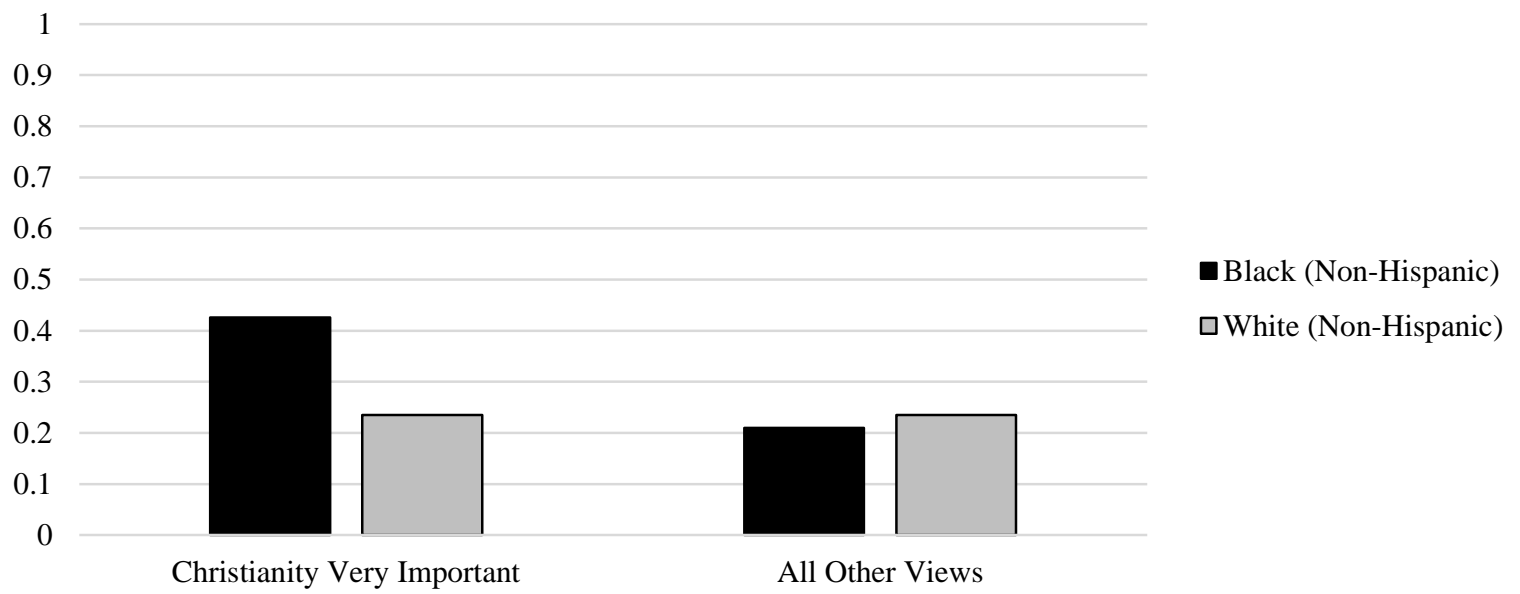

a. Predicted probability of agreement that black Americans experience worse outcomes due to discrimination.

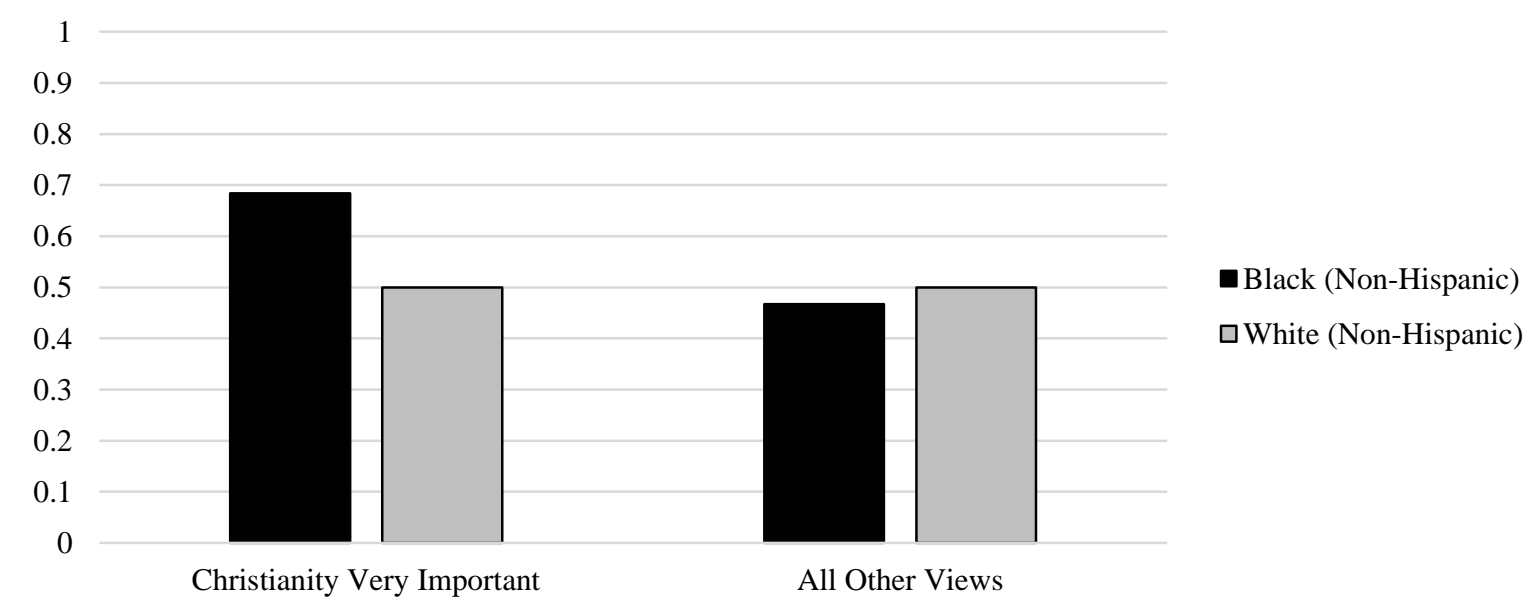

b. Predicted probability of agreement that black Americans experience worse outcomes because they do not have the chance for education that it takes to rise out of poverty.

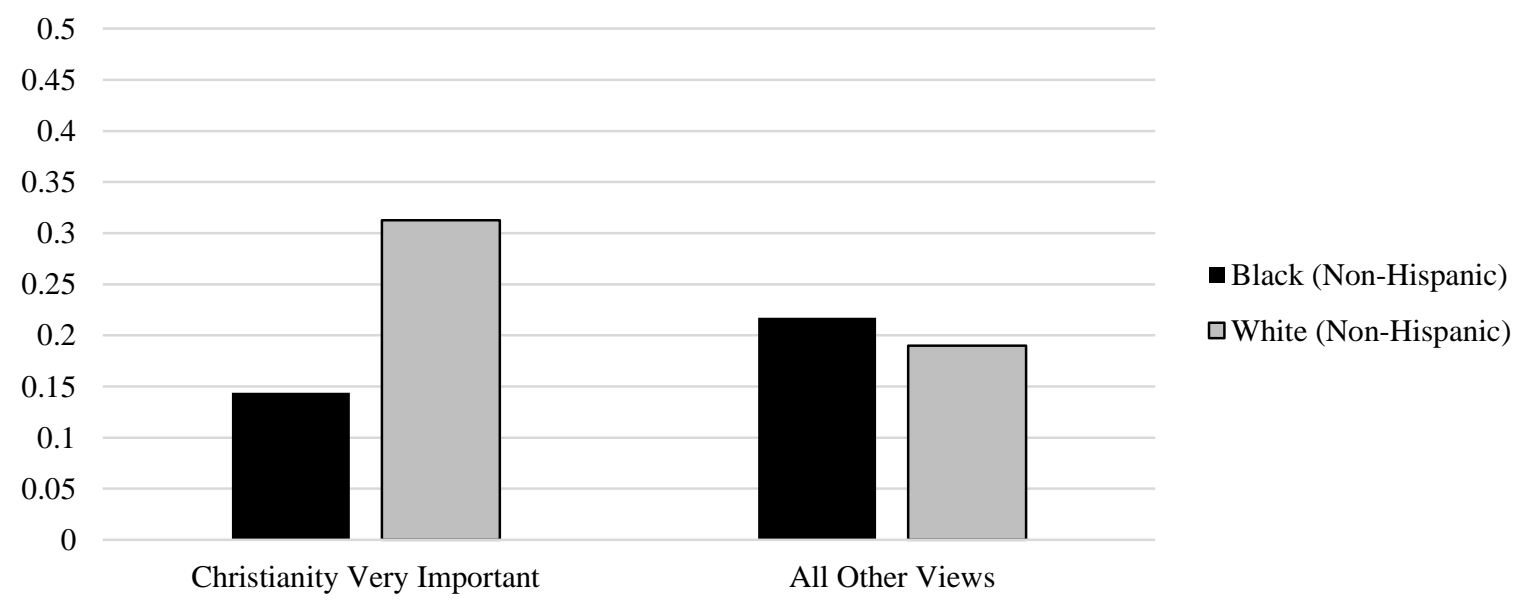

c. Predicted probability of agreement that black Americans experience worse outcomes because they do not have the motivation or willpower to pull themselves up out of poverty. 